\title{
HUMAN RESOURCE SCORECARD DALAM PENDIDIKAN NONFORMAL DAN INFORMAL
}

\author{
Widya Ayu Puspita*
}

\begin{abstract}
Human resource scorecard is a tool to record human resource performance in a card system, by focusing on long and short term and using financial and non financial indicators. There are four perspectives in this approach, which are learning and growth, internal business process, customer and finance. Human resource scorecard is not only a tactic measurement but a strategic management to manage long term strategies. This articles discusses how human resource scorecard can be implemented in the formal and nonformal organization comprehensively to increase human resource quality and to improve education organization, so that, it can give the best service to community.
\end{abstract}

Keywords: human resource scorecard, performance, non-formal and informal education

\section{PENDAHULUAN}

\section{Latar Belakang}

Pendidikan nonformal dan informal memiliki spektrum layanan masyarakat yang sangat luas, karena disesuaikan dengan karakteristik dan kebutuhan masyarakat, serta sumber daya yang tersedia. Luasnya spektrum ini menjadikan organisasi pendidikan nonformal dan informal memiliki varian yang banyak di lapangan, misalnya berbentuk Pusat Kegiatan Belajar Masyarakat (PKBM), Lembaga Pendidikan Anak Usia Dini (PAUD), dan lembaga penyelenggara kursus. Meskipun organisasi ini bervariasi, kinerja tetap harus menjadi fokus perhatian karena memiliki peran strategis mengingat bahwa pengukuran kinerja merupakan salah satu alat untuk mengetahui efektivitas dan efisiensi suatu organisasi.

Di samping itu, pengukuran kinerja merupakan isu yang strategis karena menentukan perencanaan di masa depan. Organisasi yang memiliki kinerja tinggi biasanya memiliki tingkat efisiensi dan efektivitas yang tinggi karena didasarkan pada mekanisme yang dapat dipertanggungjawabkan serta profesionalisme. Dalam pendidikan nonformal dan informal yang memiliki fleksibilitas tinggi, pengukuran kinerja membawa dampak pada kepercayaan masyarakat. Apabila kinerja organisasi PNFI baik, kepercayaan masyarakat

*Pamong Belajar BPPNFI Regional IV terhadap kualitas layanan PNFI diharapkan meningkat secara signifikan sehingga dapat menjadi alternatif pendidikan yang bermutu.

Secara umum, organisasi terdiri atas berbagai unsur yang saling terkait dalam pencapaian tujuan, demikian pula dengan organisasi PNFI yang terdiri atas berbagai unsur, antara lain sumber daya manusia, keuangan, prosedur kerja, dan bahan-bahan belajar. Setiap unsur hendaknya diukur kinerjanya agar tidak menimbulkan efek kumulatif negatif berupa kinerja organisasi yang buruk. Di samping itu, dengan penilaian kinerja secara dini dapat ditemukan unsur-unsur yang memiliki kinerja rendah untuk ditindaklanjuti.

Dari berbagai unsur ini, salah satu unsur yang penting diukur kinerjanya adalah sumber daya manusia (SDM) sangat strategis peranannya dalam pertumbuhan dan perkembangan organisasi. SDM yang strategis ini adalah adanya tiga dimensi rantai nilai (value chain) yang dikembangkan dalam arsitektur SDM yaitu fungsi (the function), sistem sumber daya manusia (the human resource system) dan perilaku pegawai (employee behavior). Fungsi menunjuk pada peran sumber daya manusia sebagai penggerak utama organisasi. Dalam PNFI, SDM merupakan motor utama bagi perancangan, pelaksanaan, penggerakan, dan penilaian program. Dengan SDM yang handal, PNFI akan diperhitungkan dalam percaturan pendidikan nasional.

Sistem SDM merupakan keseluruhan aktivitas yang di dalamnya terjadi proses transformasi 
pengubahan input awal SDM menjadi SDM yang sesuai dengan kebutuhan organisasi. Dengan adanya sistem ini, SDM ditingkatkan kapasitasnya melalui berbagai aktivitas, antara lain pendidikan dan pelatihan, magang, serta pendidikan formal, termasuk juga pengembangan karier dan jabatan. Apabila sistem ini berjalan maka organisasi tidak akan memiliki sumber daya yang "usang" sehingga akan mampu beradaptasi dengan perubahan yang serba cepat dan tidak menentu, mengikuti pola perkembangan dan tuntutan masyarakat.

Perilaku pegawai merupakan sikap dan tindakan yang ditunjukkan oleh pegawai terhadap organisasi, baik secara individu maupun berkelompok, termasuk di dalamnya komitmen, loyalitas, kedisiplinan, tuntutan, dan berbagai aspek individu lainnya. Perilaku pegawai merupakan aspek yang sangat penting karena dari sinilah image atau citra organisasi terwujud. Apabila pegawai memiliki perilaku yang baik dalam hubungan secara internal dan eksternal maka organisasi akan memiliki budaya kerja yang kondusif dan citra yang positif di hadapan masyarakat. Inilah yang perlu dibangun dalam organisasi PNFI. Keseluruhan aspek SDM inilah yang perlu diukur dan ditingkatkan selalu kinerjanya.

Pada tahun 1990-an Robert Kaplan dan David Norton menyajikan sebuah perpektif pengukuran kinerja dengan pendekatan Human Resource Scorecard (HRSC). Atkinson, Banker, Kaplan and Young (1997) menyebutkan bahwa HRSC merupakan suatu set dari target dan hasil kinerja yang digunakan sebagai pendekatan untuk mengukur kinerja yang diarahkan kepada gabungan faktor kritis dari tujuan organisasi. Sementara itu, Anthony dan Govindarajan (1997) mendefinisikan HRSC sebagai suatu alat dalam sebuah sistem untuk memfokuskan organisasi, meningkatkan komunikasi antartingkatan manjemen, menentukan tujuan organisasi, dan memberikan umpan balik yang terus-menerus terhadap keputusan yang strategis

HRSC mencoba mengukur SDM dengan mengkaitkan antara orang, strategi, dan kinerja, serta berupaya memperjelas peran SDM sebagai suatu yang dianggap intangible untuk diukur perannya, serta erat berkaitan dengan visi, misi dan strategi organisasi (Unika Atmajaya, 2007).

Hal-hal yang perlu diperhatikan dalam HRSC adalah langkah-langkah untuk melaksanakan, mulai dari proses memformulasikan SDM ke dalam peran strategis sampai dengan proses menghubungkan SDM dengan fungsi-fungsi yang dilaksanakannya ke dalam implementasi strategik organisasi. Dengan demikian, terdapat keterkaitan yang sangat erat antara pengembangan SDM dengan rencana strategis dan menjadi bagian yang tidak terpisahkan. SDM merupakan brainware yang akan menentukan pencapaian tujuan dan eksistensi organisasi (Indiyati, 2003). Dengan demikian, yang menjadi pokok masalah dalam tulisan ini adalah bagaimana konsep HRSC? dan bagaimana implementasi konsep HRSC dalam organisasi pendidikan nonformal dan informal agar terus tumbuh dan berkembang?

\section{PEMBAHASAN}

\section{Konsep HRSC}

Salah satu pendekatan pengukuran kinerja adalah HRSC yang merupakan sebuah pendekatan yang menggabungkan antara faktor-faktor sukses kritis (critical success factor) dengan strategi dan tujuan organisasi secara keseluruhan. Konsep ini menggabungkan antara sumber daya manusia dengan sumber daya lainnya, serta kontribusinya dalam organisasi.

Suryono (2007), mengemukakan bahwa dengan menggunakan HRSC kita dapat melihat suatu organisasi dalam empat perspektif. Pertama, perspektif pembelajaran dan pertumbuhan (learning and growth perspective). Perspektif ini memandang bahwa dalam sebuah organisasi terdapat berbagai kategori, antara lain: (1) kemampuan karyawan, (2) kemampuan sistem informasi, (3) motivasi, (4) pemberdayaan, dan (5) ke- sesuaian dengan standar kinerja.Ukuran intinya adalah produktivitas karyawan yang diukur dari jumlah output yang dihasilkan oleh setiap karyawan, tingkat kepuasan karyawan, tinggi rendahnya pengakuan terhadap prestasi karyawan, tingkat keterlibatan karyawan dalam proses pengambilan keputusan, kemudahan akses karyawan terhadap informasi yang menunjang pekerjaannya, dan tingkat retensi atau penolakan karyawan yang diukur dari jumlah perputaran (turn over) staf atau karyawan potensial. Manusia, system, dan prosedur menjadi kunci utama dalam perspektif ini sehingga organisasi perlu terus meningkatkan kapasitas ketiga aspek ini guna meningkatkan kinerja dalam jangka panjang.

Kedua, Internal-Business-Process Perspective. Dalam perspektif ini, pemimpin organisasi harus mengenali proses-proses kritis. Mereka harus unggul 
jika mereka akan mencapai tujuan-tujuan dari shareholder dan segmen pelanggan yang menjadi target. Sistem pengukuran performance konvensional fokus hanya pada monitoring dan peningkatan biaya, mutu, dan waktu yang didasarkan pada proses yang ada. Secara jelas, pendekatan ini memungkinkan permintaan untuk performance proses internal untuk menurunkan harapan-harapan khusus dari pihak eksternal organisasi. Dalam perspektif ini, organisasi perlu melakukan identifikasi setiap aktivitas yang dapat mengembangkan organisasi sehingga dapat mempertahankan diri dalam percaturan global yang penuh persaingan.

Ketiga, customer perspective. Perspektif pelanggan ini menggambarkan tampilan organisasi di mata pelanggan. Hal ini merupakan konsekuensi dari tingkat persaingan yang makin ketat sehingga organisasi dituntut memahami kebutuhan pelanggannya (customer driven organization) Ukuran utama dari perspektif pelanggan adalah market share, customer acquisition, customer retention, customer satisfaction, dan customer profitability. Kelima ukuran ini tidaklah terpisah-pisah, melainkan memiliki saling keterhubungan. Oleh karena itu, organisasi perlu mengidentifikasi pelanggannya dengan teliti sehingga bisa memberikan pelayanan yang sebaik-baiknya.

Keempat, financial perspective. Tujuan finansial menyajikan suatu fokus untuk tujuan dan ukuran dalam seluruh perspektif HRSC. Setiap ukuran dipilih harus menjadi bagian dari suatu hubungan sebab-akibat yang memuncak dalam peningkatan performance keuangan. HRSC menguraikan tentang strategi, dimulai dengan tujuan finansial jangka panjang, dan kemudian keterkaitannya terhadap bagian-bagian tindakan yang harus diambil dengan proses finansial, pelanggan, internal proses, dan terakhir karyawan serta sistem untuk mengantarkan performance ekonomis jangka panjang yang diharapkan. Walaupun bergantung pada daur hidup sebuah organisasi, tujuan strategi perspektif keuangan pada umumnya terkait pada upaya peningkatan pendapatan, pengurangan biaya atau peningkatan produktivitas, dan utilisasi aset organisasi, termasuk upaya-upaya meningkatkan efisiensi.

Secara skematis, konsep human resources scorecard dalam keempat perspektif di atas dapat digambarkan sebagai berikut.

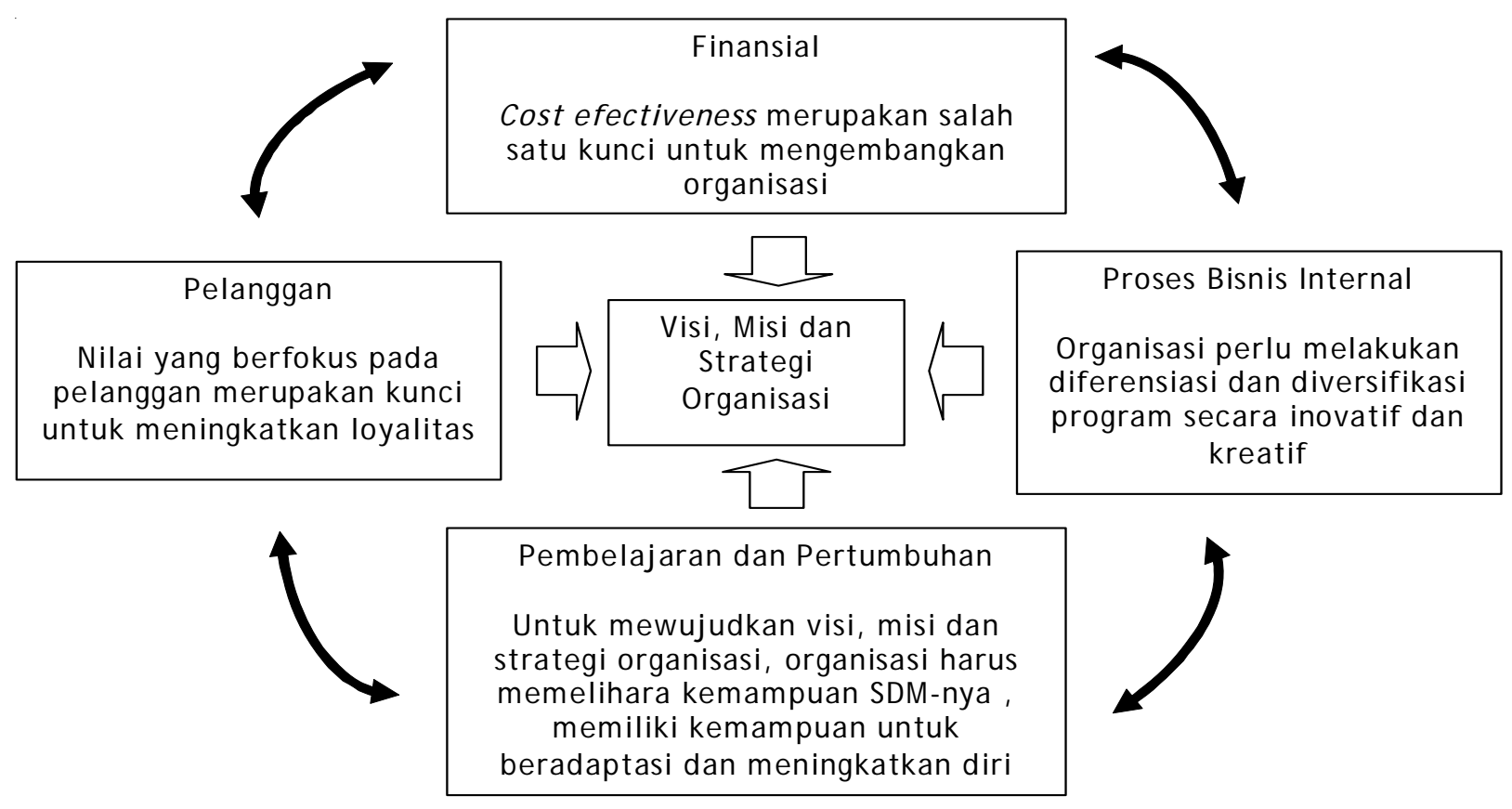

Gambar Human recources scorecard dalam empat perspektif

Dalam implementasinya, HRSC memiliki tahapan sebagai berikut (Anthony, 1997).

1. Mendefinisikan strategi. HRSC membangun hubungan yang erat antara strategi organisasi dengan kegiatan operasional yang akan dilaksanakan. Dengan demikian, perlu adanya penjabaran strategis organisasi ke dalam perencanaan operasional. Dengan demikian, sasaran-sasaran organisasi juga didefinisikan secara eksplisit.

2. Mendefinisikan pengukuran. Pengukuran yang akan dilakukan perlu didefinisikan secara operasional. Dalam mendefinisikan pengukuran ini yang perlu dilakukan antara lain: merancang dan menentukan pengukuran yang bersifat individual yang dapat mendukung strategi organisasi serta 
mengintegrasikan pengukuran dalam sistem manajemen.

3. Mengintegrasikan pengukuran kinerja ke dalam sistem manajemen sehingga pengukuran kinerja bukan hanya menjadi bagian yang parsial, atau hanya dilakukan sesaat, tanpa perencanaan, tanpa tindak lanjut, dan hasilnya diabaikan begitu saja. Pengukuran kinerja harus menjadi bagian dari sebuah sistem menajemen yang dilakukan secara sistematis, periodik, dan digunakan sebagai upaya peningkatan kinerja individu dan organisasi.

4. Meninjau hasil pengukuran kinerja secara terus menerus dan dampaknya terhadap organisasi. Beberapa pertanyaan yang dapat diajukan antara lain: (a) bagaimana perubahan strategi pengembangan SDM, (b) bagaimana cara organisasi memperbaiki proses pengukuran kinerja, (c) bagaimana dampak pengukuran kinerja terhadap layanan pelanggan, serta (d) Bagaimana komitmen SDM terhadap organisasi.

5. Menyusun laporan secara periodik. Laporan secara periodik perlu disusun sehingga dapat diketahui grafik perkembangan kinerja SDM dan organisasi secara keseluruhan.

Sebenarnya, pengukuran kinerja SDM dengan menggunakan pendekatan ini sangat berkaitan dengan pemberdayaan pegawai (employee empowerment). Pemimpin dalam hal ini hendaknya memberikan perhatian dan keleluasaan terhadap hubungan antara pegawai dengan keseluruhan proses organisasi, pelanggan, dan pembuatan keputusan. Pegawai diberikan wewenang untuk memecahkan masalah dan diberikan fasilitas untuk pengembangan dan pendekatan baru yang kreatif, dalam rangka kinerja pekerjaan dan kepuasan pelanggan (satisfying customers).

Pemberdayaan pegawai, mempunyai peranan besar dalam informasi pengukuran kinerja karena (Atkinson,1997): (1) mengindentifikasi kemungkinan efisiens, (2) menentukan prioritas proyek yang akan dikembangkan, (3) menentukan pertukaran di antara alternatif dari cara-cara untuk mengembangkan organisasi, (4) mengevaluasi usulan investasi untuk meningkatkan pertumbuhan organisasi dalam jangka panjang, (5) menjangkau konsekuensi pengembangan aktivitas. Dengan demikian pegawai mempunyai peran yang besar dalam pengukuran kinerja melalui informasi yang dihasilkan.

Pendekatan HRSC memungkinkan suatu organisasi menjadi organisasi belajar (learning organization). Suatu organisasi belajar yang efektif adalah organisasi yang memiliki pegawai pada semua tingkatan organisasi yang secara terus menerus mengamati perubahan lingkungan. Dengan demikian, para pegawai senantiasa mengindentifikasi masalahmasalah yang potensial dan peluang-peluang, saling bertukar informasi, dan melakukan percobaan model aktivitas agar dapat menyesuaikan diri dengan lingkungan yang muncul. Hal ini penting artinya guna upaya-upaya pengendalian sebagai tindak lanjut pengukuran kinerja dengan menggunakan HRSC.

Faktor-faktor kritis dalam pengendalian sangat penting artinya dalam perencanaan pengendalian, terutama apabila sering terjadi ketidakpastian. Ketidakpastian strategi pengendalian menuntut suatu "set seri informasi" yang secara interaktif saling berhubungan, up to date, serta relevan dalam pengembangan strategi baru. Ketidakpastian strategi pengendalian mengacu kepada perubahan lingkungan, misalnya preferensi pelanggan, teknologi, pesaing, gaya hidup, dan produk substitusi. Hal ini secara potensial akan mengganggu tata kerja atau sistem suatu organisasi. Pengendalian interaktif mengisyaratkan manajemen akan ketidakpastian strategi pengendalian dalam setiap perubahan kondisi lingkungan.

Penerapan HRSC secara konsisten sangat membantu pemimpin organisasi dalam mengambil keputusan, meskipun dalam situasi yang kurang menentu. Oleh karena itu, perlu dilakukan secara berkesinambungan dan menjadi bagian dari sistem manajemen secara menyeluruh sehingga perlu adanya dukungan kebijakan dalam penerapannya.

\section{Penerapan HRSC dalam PNFI}

SDM di bidang pendidikan merupakan aset yang sangat penting karena merupakan pemikir, perancang, penggerak, dan penentu bagi keberhasilan pendidikan di Indonesia. Tanpa SDM yang handal, pendidikan nonformal dan informal tidak akan dapat membantu mencapai visi dan misi pendidikan, yaitu mewujudkan insan Indonesia yang cerdas dan kompetitif. Oleh karena itu, perlu adanya perhatian yang sangat serius terhadap kinerja SDM ini yang di lapangan memiliki varian sangat luas. SDM di bidang pendidikan nonformal ini biasa dikenal sebagai pendidik dan tenaga kependidikan pendidikan nonformal (PTK-PNF).

Pengukuran kinerja bagi PTK-PNF hendaknya komprehensif karena bidang tugasnya di lapangan cukup luas, dan seringkali sulit diberikan batasan yang jelas. Oleh karena program-program pendidikan nonformal dan informal memiliki variasi sangat beragam yang disesuaikan dengan kondisi, kebutuhan dan karakteristik masyarakat. Dengan kata lain, pendidikan nonformal dan informal memiliki program yang sangat lentur dan luas. Meskipun demikian, ukuran-ukuran kinerja kuantitatif dan kualitatif perlu terus 
dikembangkan, terutama juga karena hasil pengukuran kinerja ini memberikan informasi yang sangat strategis dalam kebijakan pengembangan pendidikan nonformal dan informal di masa depan. Oleh karena itu, sepertinya konsep HRSC dapat digunakan pada sektor ini.

Konsep HRSC ini dipandang dapat digunakan dalam bidang pendidikan mengingat bahwa dalam konsep ini mengutamakan berbagai faktor sukses kritis yang terdapat pada SDM dan terdapat begitu banyak hal ini dalam diri pendidik dan tenaga kependidikan pendidikan nonformal tetapi belum dioptimalkan sesuai dengan tujuan pendidikan nasional. Berbagai faktor sukses kritis SDM PNFI perlu digali lebih lanjut sehingga dapat menghasilkan berbagai program kreatif dan inovatif. Faktor sukses kritis ini sesungguhnya merupakan modal intelektual yang tidak dapat tergantikan oleh modal atau sumber daya lainnya, misalnya mesin, prosedur, alat, dan sarana prasarana.

Rupidara

(2008)

menyebutkan bahwa secara umum berbagai faktor sukses kritis yang dapat dikembangkan antara lain: citra diri, komitmen terhadap pelanggan, kualitas layanan terhadap pelanggan, komunikasi aktif dengan

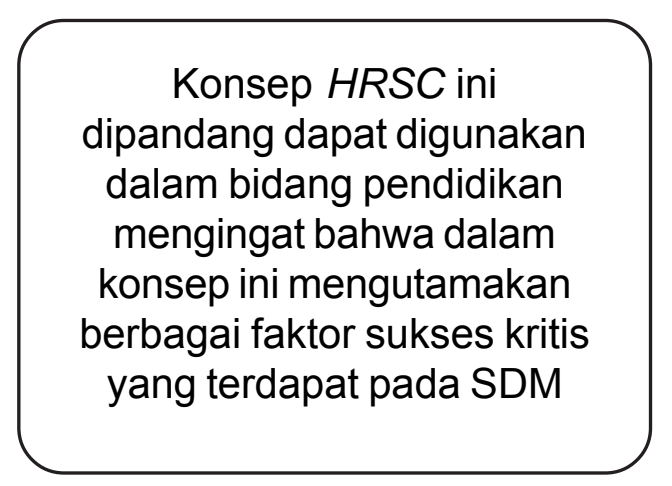

menerus melalu berbagai upaya antara lain senantiasa berdekatan dengan masyarakat, tangguh, percaya diri, dan secara optimal mencurahkan tenaga dan pikiran bagi upaya-upaya mencerdaskan kehidupan bangsa.

Keempat, komitmen terhadap pelanggan, stakeholder dan shareholder yang dalam hal ini adalah masyarakat sasaran yang memiliki karakteristik dan kebutuhan beragam, serta mitra dalam penyelenggaraan program. Sebagai wujud komitmen terhadap pelanggan, stakeholder dan shareholder, PTKPNF harus dapat memberikan kepuasan, dalam arti menberikan layanan sesuai dengan tuntutan dan kebutuhan secara aktif, kreatif, inovatif, bermutu, dan memiliki keunggulan kompetitif, serta komparatif. Untuk mewujudkan hal tersebut diperlukan kinerja yang handal sehingga dapat memberikan layanan prima dan dipercaya oleh berbagai lapisan masyarakat.

Kelima, kemampuan bekerja dalam tim. Sebagian besar tugas PTK-PNF dilaksanakan dalam bentuk tim sehingga PTK-PNF memang dituntut mampu bekerja dalam tim dalam menghasilkan karya yang bermanfaat bagi peningkatan kualitas hidup masyarakat. Keenam, pengembangan kapasitas PTKPNF. PTK-PNF senantiasa dituntut mengembangkan diri, mengingat bahwa tantangan yang dihadapi semakin kompleks dan memerlukan tingkatan keahlian yang semakin tinggi. Di samping itu, perkembangan dunia global juga menuntut kompetensi yang semakin handal, dan perlu terus "diupgrade".

Ketujuh, komitmen terhadap organisasi. PTKPNF hendaknya memiliki komitmen yang tinggi terhadap organisasi sehingga dapat memberikan yang terbaik bagi organisasi dan masyarakat. Komitmen ini sangat penting artinya dalam upaya mewujudkan kinerja yang baik.

Berbagai faktor ini merupakan potensi yang layak untuk terus digali dan dikembangkan sehingga SDM akan menjadi human capital yang dapat dimanfaatkan untuk membangun organizational capital. Hal ini dapat dilakukan dengan mendesain dan mengoperasikan organisasi pendidikan nonformal dan informal dalam proses yang cost effective, kemudian diintegrasikan dengan upaya menghasilkan value bagi customer secara sinergistik untuk mewujudkan kinerja unggul dalam jangka panjang. Untuk membangun organizational capital inilah perlu diterapkan HRSC dalam organisasi pendidikan nonformal dan informal. 
Penerapan HRSC akan membantu merancang alokasi sumber daya manusia serta aspek-aspek finansial dalam pelaksanaan kegiatan sehingga lebih efektif dan efisien. Untuk itu perlu mengintegrasikan berbagai aspek SDM (riset, perencanaan, rekruitmen, perencanaan dan pengembangan karier, peningkatan kapasitas diri, rotasi, mutasi, dan demosi) dengan berbagai aspek finansial (jumlah, alokasi, sumber dana, pemanfaatan, dan kontinuitas aliran dana).

Dengan demikian, sektor pendidikan nonformal dan informal dapat mengembangkan program-program inovatif yang unggul dan cost effective. HRSC tidak hanya memfokuskan pada ukuran keuangan semata tapi juga memperhatikan sejumlah ukuran yang terintegrasi mulai dari kualitas dan kapabilitas sumber daya manusia, kualitas proses penyelenggaraan pendidikan, kepuasan layanan untuk pencapaian kinerja keuangan dalam jangka panjang, dan memberi gambaran operasi secara menyeluruh sehingga perbaikan di satu aspek tidak merugikan aspek lainnya. Dengan kata lain, bukan hanya merupakan sekumpulan ukuran finansial dan nonfinansial saja melainkan terkait pula dengan peningkatan mutu SDM, proses penyelenggaraan, dan kepuasan atas pelayanan yang secara keseluruhan harus berdampak pada peningkatan kinerja.

Secara umum, tahapan pelaksanaan HRSC dalam pendidikan nonformal dan informal dapat dijabarkan secara garis besar sebagai berikut.

1. Mendefinisikan dan menjabarkan visi dan misi organisasi ke dalam tujuan organisasi yang operasional. Dengan demikian, terdapat keterkaitan antara visi, misi dan tujuan organisasi. Apabila tujuan organisasi telah ditetapkan maka dijabarkan lebih lanjut ke dalam program kerja yang indikator keberhasilannya dirinci dalam target-target capaian.

2. Menjabarkan peran SDM dalam pencapaian visi, misi, dan tujuan organisasi. Dalam hal ini dilakukan analisis pekerjaan sehingga jelas kualifikasi pekerjaan dan deskripsi pekerjaan. Kualifikasi pekerjaan menyangkut kriteria minimal yang harus dipenuhi dalam melaksanakan suatu pekerjaan, misalnya tingkat pendidikan, usia, serta jenis pendidikan dan pelatihan yang harus diikuti. Deskripsi pekerjaan menyangkut uraian tugas yang harus dilaksanakan, misalnya menyusun rencana kegiatan, merancang kegiatan pembelajaran, menyusun laporan, dan melakukan koordinasi lintas sektoral.

3. Mendefinisikan strategi organisasi. Strategi organisasi perlu didefinisikan secara konkret, dalam arti diuraikan secara lebih detail dalam berbagai aktivitas organisasi yang dilakukan. Strategi organisasi harus menjadi "roh" dari keseluruhan strategi yang ada pada tiap-tiap aktivitas organisasi.

4. Mendefinisikan dan menetapkan sasaran-sasaran organisasi. Penetapan sasaran memungkinkan organisasi untuk: (a) mengukur hasil jangka panjang yang ingin dicapai, (b) mengidentifikasi mekanisme dan mengusahakan sumber daya untuk mencapai hasil tersebut secara detail, dan (c) menetapkan tonggak-tonggak keberhasilan dalam jangka pendek.

5. Mengkomunikasikan visi, misi, tujuan, dan strategi organisasi kepada seluruh unsur organisasi melalui melalui berbagai media, seperti surat edaran, buletin, dan e-mail agar seluruh unsur di organisasi memahami berbagai tujuan penting yang harus dicapai agar strategi organisasi berhasil.

6. Merancang alat ukur kinerja yang bersifat komprehensif sehingga dapat mengukur seluruh aspek, baik aspek SDM, maupun aspek finansial karena HRSC mensyaratkan pengukuran secara komprehensif.

7. Mengintegrasikan pengukuran kinerja ke dalam sistem manajemen sehingga terencana dan menjadi bagian yang penting.

8. Meninjau hasil pengukuran kinerja secara terus menerus dan dampaknya terhadap organisasi.

9. Menyusun laporan secara periodik sehingga dapat diketahui hasil-hasil pengukuran kinerja dalam suatu kurun waktu tertentu dan pola-pola yang terjadi.

10. Menindaklanjuti hasil pengukuran kinerja untuk mempertahankan kinerja yang baik dan memperbaiki kinerja yang kurang.

Selanjutnya, yang perlu dilakukan adalah pengukuran kinerja secara sistematik. Proses pengukuran kinerja SDM PNF perlu dilakukan pada setiap tahap dalam siklus sebagai berikut. Pertama, seleksi pegawai sesuai dengan kebutuhan. Dalam proses seleksi hendaknya diperhatikan kebutuhan organisasi secara utuh beserta kemungkinan pengembangan karirnya. Dengan memperhatikan kebutuhan ini, kesenjangan antara kebutuhan organisasi dengan kecakapan sumber daya manusia dapat diminimalkan. Pada tahap ini pengukuran kinerja difokuskan pada kesesuaian antara kebutuhan dengan peserta yang mengikuti seleksi serta mekanisme seleksi yang dilakukan.

Kedua, penerimaan pegawai. Penerimaan pegawai merupakan proses yang sangat penting sehingga yang diterima hendaknya yang memenuhi kriteria yang telah ditentukan. Pengukuran kinerja difokuskan pada kesesuaian antara pegawai yang diterima dengan kebutuhan organisasi. Ketiga, penempatan pegawai sesuai dengan kompetensi sehingga pegawai dapat dengan mudah menyesuaikan 
diri dan mengembangkan kecakapannya dengan kesulitan yang minimal. Kesesuaian penempatan dengan kompetensi inilah yang menjadi fokus pengukuran kinerja pada tahap ini.

Keempat, pengembangan karier pegawai. Pengembangan karier merupakan aspek yang sangat penting dalam suatu siklus pengembangan SDM secara keseluruhan. Dengan adanya pengembangan karier yang terencana akan dapat menghindarkan pegawai dari frustasi dan penurunan kinerja, di samping juga meningkatkan daya saing pegawai, loyalitas, serta tanggung jawab pegawai terhadap organisasi dan diri pribadi. Pengembangan karier ini salah satunya dapat didasarkan pada hasil penilaian kinerja secara komprehensif.

Pengukuran kinerja sumber daya manusia dalam pendidikan nonformal dan informal sangat berguna dalam:

1. proses pemilihan pegawai yang handal sesuai dengan bidang tugasnya masing-masing, mengingat bahwa bidang tugas PNFI sangat luas, kompleks, dan penuh dengan tantangan karena berhubungan langsung dengan masyarakat yang memiliki karakteristik beragam;

2. meyakinkan bahwa seluruh pegawai telah memperoleh pelatihan yang sesuai dengan kebutuhan, dengan demikian dapat melaksanakan tugas pokok dan fungsinya secara optimal dan memberikan layanan prima dalam kerangka mencerdaskan bangsa;

3. memutuskan dan menempatkan pegawai yang sesuai dalam organisasi sehingga dapat memenuhi kriteria "the right man in the right job". Apabila kriteria ini terpenuhi, pegawai akan dengan mudah beradaptasi dan berkembang sehingga tidak mengalami frustasi dalam pekerjaan;

4. memberi wewenang dan tanggung jawab sesuai dengan kompetensi masing-masing individu dan kebutuhan organisasi sehingga memudahkan dalam perencanaan karier, baik dalam jabatan fungsional maupun struktural. Perencanaan dan pengembangan karier pegawai memberikan harapan untuk terus meningkatkan kapasitas diri sehingga memiliki daya saing yang tinggi;

5. pelaksanaan disiplin organisasi. Penilaian kinerja pada awalnya mungkin bersifat "memaksa" pegawai untuk berdisiplin tetapi pada akhirnya akan menciptakan sebuah kebiasaan untuk berdisiplin;
6. pemberian nasihat dan saran guna peningkatan kapasitas individu sesuai dengan perencanaan karier;

7. perancangan sistem karier pegawai sehingga meningkatkan loyalitas pegawai kepada organisasi;

8. meyakinkan bahwa lingkungan kerja cukup kondusif dan memuaskan bagi sebagian besar pegawai sehingga produktivitas dapat terus ditingkatkan. Produktivitas yang tinggi diharapkan akan meningkatkan kepuasaan stakeholder, shareholder, dan para pelanggan sehingga meningkatkan peran strategis pendidikan nonformal dan informal dalam sistem pendidikan nasional;

9. membantu memecahkan masalah yang berkaitan dengan pelaksanaan tugas masing-masing pegawai sehingga dapat meningkatkan kinerja;

10. menyetujui tindakan yang diusulkan yang boleh diambil dan yang tidak boleh diambil oleh pegawai;

11. berinteraksi dengan seluruh unit organisasi sehingga timbul rasa saling percaya;

12. kerja sama dalam rangka memecahkan masalah yang menghambat pekerjaan dan memberikan pertanggungjawaban yang terpercaya bagi organisasi; dan

13. berusaha menciptakan iklim yang mendorong pekerjaan untuk bekerja secara efektif dan efisien sehingga seluruh unsur terpacu untuk memberikan yang terbaik bagi organisasi dan masyarakat.

Dengan demikian, perlu rancangan instrumen penilaian kinerja SDM secara sistematis, terarah, teratur dan terencana, dengan dukungan dari semua pihak, terutama pengambil kebijakan. Tanpa adanya dukungan ini, pengukuran kinerja tidak akan berhasil guna, terutama dalam perancangan tindak lanjut. Strategi HRSC mendorong adanya dialog antara PTKPNF dengan jajaran eksekutif sehingga hasil pengukuran kinerja dapat diketahui dan diterima secara terbuka, guna peningkatan kinerja dan perumusan dan pelaksanaan strategi yang menghasilkan terobosan kinerja masa depan.

Dengan demikian setiap orang di dalam organisasi harus memiliki tujuan-tujuan jangka panjang dan juga strategi untuk mencapai tujuan-tujuan tersebut. Secara individu PTK-PNF yang ada akan merumuskan berbagai tindakan lokal yang akan memberi kontribusi bagi tercapainya tujuan-tujuan unit bisnis. Semua aktivitas serta inisiatif organisasi akan disesuaikan dengan proses perubahan yang dibutuhkan.

\section{KESIMPULAN}

HRSC merupakan suatu sistem manajemen yang menjabarkan visi dan strategi suatu organisasi ke dalam tujuan operasional dan tolok ukur. Tujuan dan tolok ukur dikembangkan untuk setiap perspektif 
keuangan, pelanggan, proses usaha internal serta pembelajaran dan pertumbuhan. Pengukuran untuk keempat perspektif ini tergantung dari strategi yang telah ditetapkan organisasi sebelumnya. Oleh karena itu, HRSC selain dapat digunakan sebagai alat pengukur kinerja, juga dapat digunakan sebagai alat untuk menilai apakah strategi yang dilakukan sudah tepat, dan juga untuk mengawasi apakah strategi organisasi telah dijalankan, termasuk organisasi pendidikan nonformal dan informal.

Perkembangan dunia pendidikan nonformal dan informal menjadikan SDM sebagai aset utama dan strategis dalam mencapai visi dan misi organisasi sehingga peningkatan kompetensi dan profesionalisme menjadi tuntutan mutlak yang harus dipenuhi. Dunia pendidikan nonformal dan informal harus dapat menyesuaikan diri terhadap perubahan-perubahan lingkungan yang berlangsung cepat sehingga harus proaktif dan cost-effective.

Menjawab tantangan ini, pemimpin organisasi harus dapat mengelola organisasi agar tetap tumbuh dan berkembang sesuai dengan tuntutan perubahan. Strategi SDM yang mengacu kepada pengetahuan, pendidikan, pelatihan, keahlian, dan keahlian, kini menjadi sangat penting dalam memberikan kontribusi pada kinerja organisasi. Oleh karena itu perlu dilakukan pengukuran terhadap kinerja SDM, yang salah satunya dengan menggunakan pendekatan HRSC, sebagaimana diuraikan di atas. Dengan menggunakan pendekatan ini PNFI dapat merancang strategi untuk kinerja yang unggul yang umumnya menuntut investasi yang signifikan pada orang, sistem dan proses yang mampu membangun kemampuan organisasi untuk terus tumbuh dan berkembang.

\section{DAFTAR PUSTAKA}

Indiyati, D. (2003). Human resources scorecard suatu pengukuran kinerja sumber daya manusia. Jurnal Manajemen Vol. 11 No. 2. Fakultas Ekonomi Unika Atmajaya. Jakarta.

Kaplan, R.S. dan Norton, D.P. (1996). The balanced scorecard: Translating strategy into action. Harvard Business School Press. Boston.

Rupidara, N. (2008). Modal intelektual dan strategi pengembangan organisasi dan sumber daya manusia. Makalah. Pusat Studi Kawasan Timur Indonesia. Universitas Kristen Satya Wacana.

Suryono. (2007). Balance scorecard. Fakultas Ekonomi - Universitas Jenderal Achmad Yani.

Unika Atmajaya. (2007). Perancangan human resources scorecard untuk mengukur kinerja departemen human resource. (Studi Kasus: PT. Sucaco, Tbk). Jakarta: Perpustakaan Unika Atmajaya. 